УДК 343.8

О. Г. Колб

доктор юридичних наук, професор,

професор кафедри кримінального права та процесу

Навчально-наукового інституту права, психології та інноваційної освіти

Національного університету “Львівська політехніка"

Л. М. Дучимінська

начальник Управління внутрішнього

аудиту та фінансового контролю

головного управління

Пенсійного фонду України

у Волинській області,

lesya5@meta.ua

ПРО ДЕЯКІ ОБОВ'ЯЗКИ ДЕРЖАВНИХ ОРГАНІВ, ЩО ПОВ'ЯЗАНІ ІЗ ВИКОНАННЯМ ПОКАРАННЯ

У ВИДІ ПОЗБАВЛЕННЯ ПРАВА ОБІЙМАТИ ПЕВНІ ПОСАДИ

АБО ЗАЙМАТИСЯ ПЕВНОЮ ДІЯЛЬНІСТЮ ЩОДО ЗАСУДЖЕНИХ

У СФЕРІ ПЕНСІЙНОГО ТА СОЦАЛЬНОГО

ЗАКОНОДАВСТВА УКРАЇНИ

(C) Колб О. Г., Дучимінська Л. М., 2019

На підставі здійсненого аналізу змісту визначених у законі обов'язків для органів пробації виявлено проблемні питання, що стосуються виконання покарання у вигляді позбавлення права обіймати певні посади або займатись відповідною діяльністю відносно засуджених за злочини у сфері пенсійного та соціального забезпечення України, а також запропоновано науково обгрунтовані заходи щодо їх вирішення по суті.

Ключові слова: обов'язок; уповноважений орган 3 питань пробації; закон; покарання; позбавлення права обіймати певні посади чи займатись певною діяльністю; засуджений; суд; злочин.

А. Г. Колб, Л. М. Дучиминская

О НЕКОТОРЫХ ОБЯЗАННОСТЯХ ГОСОРГАНОВ, КОТОРЫЕ

КАСАЮТСЯ ИСПОЛНЕНИЯ НАКАЗАНИЯ В ВИДЕ ЛИШЕНИЯ ПРАВА ЗАНИМАТЬ ОПРЕДЕЛЕННЫЕ ДОЛЖНОСТИ

ИЛИ ЗАНИМАТЬСЯ ОПРЕДЕЛЕННЫМИ ВИДАМИ ДЕЯТЕЛЬНОСТИ ОТНОСИТЕЛЬНО ОСУЖДЕННЫХ В СФЕРЕ ПЕНСИОННОГО И СОЦИАЛЬНОГО ЗАКОНОДАТЕЛЬСТВА УКРАИНЫ

На основании проведенного анализа содержания установленных в законе обязанностей для органов пробации определены проблемные вопросы, относящиеся к исполнению наказания в виде лишения права занимать соответствующие должности или заниматься соответствующей деятельностью относительно осужденных за преступления в сфере пенсионного и социального обеспечения Украины, а также предложены научно обоснованные мероприятия, направленные на их решение по существу.

Ключевые слова: обязанность; уполномоченный орган по вопросам пробации; закон; наказание; лишение права занимать соответствующие должности или заниматься соответствующей деятельностью; определённый; суд; преступление. 

professor of the department of criminal

Law and Process of the National

Lviv Polytechnic University

L. M. Duchiminskaya Head of Internal Affairs audit and financial control the main directorate of the pension Fund of Ukraine in the Volyn region

\section{ON SOME DUTIES OF THE STATE AUTHORITIES THAT RELATE TO THE EXECUTION OF PUNISHMENT IN THE FORM OF DEPRIVATION OF RIGHT HUGGING CERTAIN POSITIONS OR ENGAGE CERTAIN ACTIVITIES ON CONVICTS IN THE SPHERE OF PENSION AND SOCIAL LEGISLATION OF UKRAINE}

In the article, based on the analysis of the content of the duties specified by the law for probation bodies, the problem issues concerning the execution of a sentence in the form of deprivation of the right to occupy certain positions or to engage in appropriate activities regarding those convicted of crimes in the sphere of pensions and social security of $U$ kraine, as well as Proposed scientifically substantiated measures on their solution in essence.

Key words: duty; the authorized body on probation; law; punishment; deprivation of the right to occupy certain positions or engage in certain activities; condemned; court; crime.

Постановка проблеми. Одним із невід'ємних змістовних елементів правового статусу будьякої особи (фізичної та юридичної) $є$ наявність у неї обов'язків.

Як 3 цього приводу зазначено в ст. 23 Конституції України, кожна людина має право на вільний розвиток своєї особистості, якщо при цьому не порушуються права і свободи інших людей, та має обов'язки перед суспільством, в якому забезпечується вільний і всебічний розвиток ії особистості [1].

У тлумачних словниках під обов'язком розуміють те, чого потрібно беззастережно дотримуватися, що слід безвідмовно виконувати відповідно до вимог суспільства або виходячи 3 власного сумління: певний обсяг роботи; сукупність справ, межі відповідальності й т. ін., що визначається відповідним званням, посадою тощо [2, с. 450].

В юридичній літературі вживається словосполучення “юридичний обов'язок”, який означає встановлену нормами права міру належної поведінки особи [3, с. 239]. При цьому юридичний обов'язок передбачає необхідність:

а) здійснити певні дії або утриматись від них;

б) відреагувати на законні вимоги уповноваженої особи;

в) не перешкоджати уповноваженій особі користуватися благами, на які вона має право;

г) відповідати за невиконання своїх обов'язків [3, с. 239-240].

Якщо виходити із зазначених методологічних засад та з результатів аналізу змісту нормативноправових актів, які регулюють діяльність уповноважених органів з питань пробації в Україні, то треба констатувати, що юридичні обов'язки для цих суб'єктів кримінально-виконавчих правовідносин визначено дещо схоластично (від гр. scholastikos - шкільний; формальні знання, відірвані від життя та практики $[4$, с. 560]) та безсистемно. У ст. 31 КВК України “Обов' язки уповноваженого органу 3 питань пробації щодо виконання покарання у виді позбавлення права обіймати певні посади або займатися певною діяльністю" мова про обов'язок взагалі не ведеться, а лише перераховано певні завдання, які має здійснювати цей суб'єкт кримінально-виконавчої діяльності [5]. 
Аналогічний підхід застосовано законодавцем й у Законі України "Про пробацію", в ч. 1 ст. 18 якого зазначено, що орган пробації у межах своїх повноважень організовує здійснення певних заходів [6]. I навіть більше, цей “базовий” нормативно-правовий акт для уповноважених органів 3 питань пробації не повною мірою кореспондується зі змістом, зокрема, ч. 1 ст. 31 КВК, не вказуючи таких юридичних обов'язків цього суб'єкта права, як: ведення обліку засуджених; роз'яснення прав для засуджених; здійснення контролю тощо.

Ще складніше та хаотичніше вирішено це питання у Типовому положенні про уповноважений орган 3 питань пробації, яке затверджено наказом Міністерства юстиції України від 18.08.2017 p. № 2649/5 [7]. У розділі II цього Положення закріплено основні завдання та функції органу пробації, в яких зокрема визначено й обов'язки вказаного суб'єкта кримінально-виконавчих правовідносин; у розділі III - встановлено права персоналу органу пробації; у розділі IV повноваження цих осіб, а в п. 2 р. IV цього Положення - обов'язки начальника органу пробації. Крім цього, в п. 1 р. V цього Положення зазначено, що службові обов'язки персоналу органу пробації визначаються посадовими інструкціями, які затверджує директор Центру пробації.

Такий самий юридичний “хаос" з цих питань трапляється і в інших нормативно-правових актах, що стосуються діяльності органів пробації, що, як свідчить практика та доведено на доктринальному рівні [8], вкрай негативно впливає на ефективність діяльності у сфері виконання покарань та пробації загалом.

Отже, ураховуючи результати проведеного аналізу, нормативно-правові акти, що встановлюють обов'язки для уповноваженого органу з питань пробації, поклавши в основу критерій нормативної визначеності, можна поділити (класифікувати) на три групи, а саме:

а) до першої із них слід зарахувати Закон України "Про пробацію”, в якому у загальних рисах закріплено ці обов'язки (ст. 18);

б) до другої - норми спеціального змісту, що безпосередньо стосуються обов'язків органу пробації та виконання покарання у вигляді позбавлення права обіймати певні посади або займатися певною діяльністю (ст. 31 КВК України);

в) до третьої - положення інших нормативно-правових актів, які визначають конкретні обов'язки посадових осіб уповноваженого органу 3 питань пробації (Типове положення про уповноважений орган з питань пробації (розділ II та IV, V), а також Типове положення про сектор ювенальної пробації).

Аналіз дослідження проблеми.. Як показало вивчення наукової літератури, у сучасних умовах доволі активно та результативно над проблематикою виконання покарання у вигляді позбавлення права обіймати певні посади або займатись відповідною діяльністю працюють такі учені, як: Ю. В. Баулін, Є. Ю. Бараш, В. С. Богатирьова, І. Г. Богатирьов, О. І. Богатирьова, А. П. Гель, Б. М. Головкін, В. Н. Грищук, О. М. Джужа, Т. А. Денисова, Р. М. Гура, О. М. Звенигородський, В. О. Навроцький, А. В. Савченко, А. Х. Степанюк, С. Я. Форенюк, І. С. Яковець та ін.

Водночас, враховуючи останні зміни, внесені у чинне кримінально-виконавче законодавство України та гуманізацію процедури виконання покарань у 2014-2019 рр., а також необхідність наукового супроводу реалізації у сфері виконання покарання у виді позбавлення права обіймати певні посади або займатись відповідною діяльністю прийнятих державних програм, треба визнати, що ця наукова стаття актуальна і має теоретичне та практичне значення.

Отже, існує складна прикладна проблема, що потребує вирішення, зокрема й на науковому рівні, що й зумовило вибір теми цієї статті, а також визначило ії основну мету - на основі проведеного аналізу закріплених у законі обов'язків органу пробації розробити науково обгрунтовані заходи, спрямовані на удосконалення виконання покарання у вигляді позбавлення права обіймати певні посади або займатись певною діяльністю відносно засуджених за злочини у сфері пенсійного та соціального забезпечення.

Виклад основного матеріалу. Якщо за основу взяти положення п. 1 ст. 92 Конституції України про те, що тільки законами визначаються зокрема основні обов'язки громадянина, а також вимоги ст. 31 КВК України як систематизованого та кодифікованого [9, с. 451-456] нормативно- 
правового акта, що стосується цієї проблематики, то до обов'язків уповноваженого органу з питань пробації щодо виконання покарання у вигляді позбавлення права обіймати певні посади або займатися певною діяльністю засуджених, зокрема за злочини у сфері пенсійного та соціального забезпечення України, необхідно зарахувати такі:

1. Ведення обліку засуджених до цього виду покарань.

Облік - це засвідчення, встановлення наявності, з'ясування кількості чого-небудь; реєстрація людей із занесенням у відповідні списки для їх використання де-небудь; з'ясування їх наявності; система реєстрації процесів якої-небудь діяльності в ії кількісному та якісному виявах з метою спрямування, контролю тощо [10, с. 108].

Згідно з вимогами відомчих нормативно-правових актів Міністерства юстиції України, облік засуджених до покарання у вигляді позбавлення права обіймати певні посади або займатися певною діяльністю здійснюється щодо таких категорій цих осіб:

а) засуджених до цього основного покарання;

б) засуджених до інших основних покарань, не пов'язаних із позбавленням волі та щодо яких судом визначено додаткове покарання у вигляді позбавлення права обіймати певні посади або займатися певною діяльністю;

в) засуджених до обмеження та позбавлення волі та додаткового покарання у виді позбавлення права обіймати певні посади або займатися певною діяльністю, звільнених від покарання та його відбування відповідно до закону про кримінальну відповідальність (ст. ст. 74-87 КК України) [11].

Реєстрацію зазначених категорій осіб здійснює відповідна посадова особа територіального уповноваженого органу з питань пробації в порядку, встановленому ст. 30 КВК та відомчими нормативно-правовими актами Міністерства юстиції України.

Після взяття засудженого на облік органу пробації його керівник, як передбачено п. 2 p IV Типового положення про уповноважений орган пробації, у встановлені законом терміни (як правило, в десятиденний строк), направляє письмове повідомлення до суду, який постановив вирок (ухвалу) (ч. 4 ст. 535 КПК України), а також органу та установі виконання покарань, 3 яких було звільнено зазначену особу згідно з визначеними у законі підставами (ст. 152-153 КВК), а також в інші органи державної влади та управління (підрозділи у справах громадянства і міграції; органи, які мають право анулювати дозвіл займатися певними видами діяльності; податкову службу; пенсійний фонд тощо) [10, с. 108], а також здійснює інші дії, що передбачені чинними нормативноправовими актами з питань діловодства [12].

2. Роз'яснення засудженим особам порядку та умов відбування покарання у вигляді позбавлення права обіймати певні посади або займатися певною діяльністю.

Зазначений обов'язок уповноваженого органу з питань пробації випливає зі змісту ст. 57 Конституції України, відповідно до якої закони та інші нормативно-правові акти, що визначають права та обов'язки громадян, мають бути доведені до відома населення у порядку, встановленому законом. Крім цього, цей обов'язок обумовлений правовим статусом засудженого, основи якого визначено в ст. 7 КВК та, безпосередньо, - в ч. 1 ст. 8 цього Кодексу, а саме: засуджені мають право на отримання інформації про свої права та обов'язки, порядок і умови виконання та відбування призначеного судом покарання. Адміністрація установи чи органу, який виконує покарання, зобов'язана надати засудженим зазначену інформацію, а також ознайомлювати їх зі змінами порядку й умов відбування покарань.

Як показує практика, для ознайомлення засуджених до покарання у виді позбавлення права обіймати певні посади або займатися певною діяльністю передбачено таку процедуру:

a) після взяття цієї особи на облік іiі відразу викликають до територіального органу з питань пробації за місцем ії проживання для реалізації положень, що викладені в ст. 8 КВК України, а також роз'яснення правових наслідків у разі порушення встановленого порядку виконання відбування цього покарання та ухилення від відбування покарання у виді позбавлення права обіймати певні посади або займатися певною діяльністю (ч. 1 ст. 386 КК України). 
У письмовому повідомленні про виклик засудженого до органу пробації зазначається обов'язок особи про прибуття у встановлене місце і час (вказується місце реєстрації та знаходження уповноваженого органу з питань пробаціі), а також про надання цьому державному органу таких документів: 1) довідки з місця роботи про те, яку посаду засуджений обіймає або обіймав до рішення суду чи який вид робіт виконував (виконує), або копії трудового договору (угоди, контракту тощо); 2) трудової книжки та ксерокопії з неї для осіб, які не працюють.

Надалі зазначені документи засудженим надають на вимогу територіального уповноваженого органу з питань пробації один раз на рік до закінчення строку відбування цього виду покарання [10, c. 109].

Копії повідомлення та інших реєстраційних матеріалів вихідної кореспонденції журналу обліку органу пробації долучають до особової справи засудженого до покарання у вигляді позбавлення права обіймати певні посади або займатися певною діяльністю;

б) після роз'яснення засудженому його правового статусу та правових наслідків у разі порушення вимог закону та ухилення від відбування визначеного рішенням суду покарання у ході безпосередньої співбесіди 3 ним посадової особи органу пробації засуджений дає письмову підписку про виконання обов'язків та законних вимог уповноваженого органу з питань пробації, яку долучають до його особової справи, він заповнює анкету встановленої форми, яка також приєднується до зазначеної справи;

в) у випадках, коли у засудженого виникають питання, що стосуються виконання вироку, посадова особа органу пробації роз'яснює йому положення ст. 380 КПК “Роз'яснення судового рішення” та ст. 539 КПК “Порядок вирішення судом питань, пов'язаних із виконанням вироку”, а також право останнього щодо звернення у суд з цього предмета [13].

3. Здійснення контролю за засудженими, за додержанням порядку та умов відбування покарання у вигляді позбавлення права обіймати певні посади або займатися певною діяльністю.

У науковій літературі під контролем (від франц. controle - перевірка; список, що має дублікати для перевірки) [4, с. 290] розуміють перевірку стану певного виду суспільної діяльності [10, c. 109].

Результати вивчення практики свідчать про те, що свої контрольні зобов'язання уповноважений орган з питань пробації здійснює шляхом:

a) перевірки засуджених до покарання у вигляді позбавлення права обіймати певні посади або займатися певною діяльністю за місцем їх роботи.

За іii результатами посадова особа органу пробації складає акт у двох примірниках, один 3 яких залишається на підприємстві, в установі, організації, а інший з позначкою про ознайомлення 3 ним власника (керівника) юридичної особи та засудженого долучається до особової справи останнього, а також використовується для усунення виявлених недоліків;

б) щорічного (одноразового) звіряння документів і записів у них (повідомлень про виклик до органу пробації; підписів засудженого; актів перевірки тощо);

в) нагляду за поведінкою зазначеної категорії засуджених, для чого один раз на три місяці надсилають письмові запити про те, чи притягувалися ці особи до адміністративної чи інших видів юридичної відповідальності.

У наукових джерелах слово “нагляд” тлумачиться як “наглядати”, тобто як пильнувати, слідкувати за ким-, чим-небудь для контролю, забезпечення порядку тощо [2, с. 393].

Як показує практика, нагляд за засудженими до позбавлення права обіймати певні посади або займатися певною діяльністю здійснюється у гласних чи негласних формах. Остання форма, зокрема, визначена Законом України "Про оперативно-розшукову діяльність", в ст. 5 якої до суб’єктів цієї суспільно-правової діяльності зараховано й органи пробації [14]. Крім цього, уповноважений орган з питань пробації, як випливає зі змісту ст. 246 КПК, слідчий може залучати до проведення негласних слідчих (розшукових) дій у випадках вчинення злочинів 3 боку засуджених у вигляді позбавлення права обіймати певні посади або займатися певною діяльністю $[15$, c. $628-632]$. 
4. Здійснення контролю за додержанням вимог судового рішення власником підприємства, установи, організації або уповноваженим органом за місцем роботи засудженого, а також органом, що має право анулювати дозвіл на заняття відповідним видом діяльності, забороненим засудженому.

Зазначений обов'язок органу пробації тісно пов'язаний із поняттям “власність”, що важливо враховувати під час його реалізації.

Зміст останнього сформульовано в ст. 316 Цивільного кодексу України [16].

Загалом, відповідно до цивільного законодавства України, суб'єктами права власності $є$ український народ та інші учасники цивільних правовідносин, що визначені в законі (зокрема, в ст. 2 ЦК). Зважаючи на це, власникові належить право володіння, користування та розпорядження своїм майном, і на зміст права власності не впливають місце проживання власника та місце знаходження майна [10, с. 109].

Отже, якщо врахувати, що відповідно до вимог ч. 4 ст. 13 Конституції України всі суб'єкти права власності рівні перед законом, та те, що засуджені до винесення судового рішення та після вступу його у законну силу (ст. 532-535 КПК України) мають право вільно вибирати собі місце роботи (ч. 1 ст. 43 Конституції України), уповноважений орган 3 питань пробації має право контролювати додержання вимог вироку (ухвали) суду на підприємствах, в установах та організаціях будь-якої форми власності, де працює засуджений до покарання у вигляді позбавлення права обіймати певні посади або займатися певною діяльністю. Потрібно враховувати, що відповідно до положень підрозділу 2 "Юридична особа” ЦК України під підприємством, установою чи організацією слід розуміти ті юридичні особи, які створені та зареєстровані в установленому законом порядку.

3 цього випливає висновок про те, що під час здійснення контролю за додержанням вимог судового рішення власником підприємства, установи, організації або уповноваженим ним органом за місцем роботи засудженого (зокрема Пенсійним фондом та соціального захисту населення), посадові особи уповноваженого органу з питань пробації не тільки мають право, але й зобов'язані перевіряти у цих юридичних осіб їні установочні та реєстраційні документи, щоб запобігти вчиненню злочинів як з боку засуджених, так й інших осіб (ч. 1 ст. 1 КВК України).

Ще одним об’єктом контролю з боку органу пробації, згідно з ч. 1 ст. 31 КВК, є орган, що має право анулювати дозвіл на заняття відповідним видом діяльності, що заборонена засудженому на підставі рішення суду.

До таких органів належать:

1) кадрові апарати підприємств, установ або організацій, де працює (чи працював) засуджений до такого виду покарання;

2) органи, які здійснюють ліцензування певних видів діяльності;

3) громадські об'єднання (спілки мисливців, рибалок, охорони навколишнього середовища тощо);

4) окремі підприємці-фізичні особи, що самостійно приймають і звільняють 3 роботи працівників [10, с. 110].

Саме тому, як це випливає зі змісту п. 17 постанови Пленуму Верховного Суду України від 24 жовтня 2003 року № 7 “Про практику призначення судами кримінального покарання”, рішення про позбавлення права обіймати певні посади або займатися певною діяльністю повинно бути чітко сформульоване в резолютивній частині вироку (ухвали), для того, щоб не виникло жодних сумнівів під час виконання останнього. Якщо в санкції статті (санкції частини статті) Особливої частини КК зазначено характер посад або вид діяльності (наприклад, ст. 286, 287), рішення про призначення додаткового покарання, наведене в резолютивній частині вироку (ухвали), повинно відповідати змісту цієї санкції $[17$, с. 240$]$.

5. Вжиття заходів для припинення порушень вимог судових рішень.

Як показує практика, зазначена діяльність посадових осіб уповноваженого органу з питань пробації здійснюється у трьох формах, а саме: 
а) безпосереднього впливу на правопорушника (наприклад, у ході перевірки підприємства, організації, установи представник органу пробації зобов'язує їх керівників забезпечити виконання обов'язків, визначених у ст. 32 КВК України, та попереджує про правові наслідки їх невиконання (ч. 2 ст. $31 \mathrm{KBК)).}$

Аналогічні дії відповідної посадової особи уповноваженого органу з питань пробації: він попереджує засудженого про необхідність чітко виконувати обов'язки, визначені у ст. $34 \mathrm{KBК,} \mathrm{а}$ також бере у цих осіб письмові пояснення, які долучає до їхніх особових справ, та попереджує про правові наслідки ухилення від відбування покарання у вигляді позбавлення права обіймати певні посади або займатися певною діяльністю, мова про які ведеться в ст. 35 КВК);

б) впливу на правопорушника спільно з працівниками прокуратури, який здійснюється на підставі вимог ст. 22 КВК та Закону України “Про прокуратуру” визначеними формами, методами, засобами [18];

в) впливу на засудженого тими можливостями, що закріплені в законі (ст. 35 КВК “Наслідки ухилення від відбування покарання у виді позбавлення права обіймати певні посади або займатися певною діяльністю” та ст. 389 КК “Ухиляння від покарання, не пов'язаного з позбавленням волі”). Варто зазначити, що у цьому випадку, як свідчить практика, відсутність у КВК України, як, власне, i в інших нормативно-правових актах 3 означених питань дисциплінарної відповідальності засуджених до позбавлення права обіймати певні посади або займатися певною діяльністю, є однією із ключових обставин, яка не дає змоги кваліфікувати їх протиправну діяльність як ухилення від відбування цього покарання.

6. Вжиття першочергових засобів з виявлення засуджених, місцезнаходження яких невідоме.

Порядок реалізації зазначеного обов'язку уповноваженого органу 3 питань пробації визначається відомчими нормативно-правовими актами Міністерства юстиції України та стосується всіх, без винятку, покарань, виконання яких покладається на орган пробації. Зокрема, у п. 3 розділу IV Типового положення про уповноважений орган з питань пробації закріплена одна із правових гарантій такої діяльності, а саме: начальник органу пробації має право одержувати в установленому порядку від державних органів та органів місцевого самоврядування, підприємств, установ та організацій інформацію, необхідну для виконання завдань, покладених на орган пробації [7].

У цьому контексті варто назвати першочергові заходи щодо виявлення засуджених, місцезнаходження яких невідоме:

1) звернення посадових осіб уповноваженого органу з питань пробації через різні канали (електронну пошту, телефон, з письмовим запитом тощо) до органів охорони здоров'я, щоб встановити факт перебування засудженого на лікуванні або тяжкого захворювання, яке не дає змогу встановити особу хворого, чи смерті останнього;

2) звернення у територіальний орган Національної поліції для встановлення факту перебування у ньому засудженого (адміністративний арешт, притягнення його до кримінальної відповідальності тощо);

3) звернення до адміністрації підприємств, установ та організацій, у яких працює засуджений, про місце його працевлаштування (в цьому випадку до органів Пенсійного фонду та соціального захисту) (відрядження, переведення на інше місце роботи, переведення на роботу в іншу місцевість тощо);

4) безпосереднє відвідування посадовою особою органу пробації місця проживання засудженого (як реєстрації, так і безпосереднього проживання), його огляд з метою виявлення цієї особи, опитування співмешканців, сусідів, інших громадян);

5) інші заходи, що проводяться з метою встановлення місцезнаходження засудженого, зокрема оперативно-розшукові, визначені в Законі України "Про оперативно-розшукову діяльність".

У випадку, коли заходи із встановлення місцезнаходження засудженого не дали позитивного результату, зібрані органом пробації матеріали передаються у територіальний орган Національної поліції для оголошення його в розшук. Відповідальні особи уповноваженого органу 3 питань пробації й надалі здійснюють заходи для встановлення місця перебування засудженого. 
7. Звернення до відповідних правоохоронних органів щодо розшуку засуджених, місцезнаходження яких невідоме.

Порядок взаємодії уповноважених органів пробації та відповідних правоохоронних органів регулюється спільними наказами центральних органів виконавчої влади України, він охоплює, зокрема, й питання щодо спільного розшуку засуджених, місцезнаходження яких невідоме.

Порядок розшуку осіб, місцезнаходження яких невідоме, а також осіб, яким вручено підозру про вчинення злочину, та інших категорій розшукуваних осіб визначається відповідними інструкціями правоохоронних органів України та чинним кримінальним процесуальним законодавством, які поширюються, зокрема, на засуджених усіх видів. До таких, зокрема, належать:

а) Інструкція 3 організації функціонування Інтегрованої інформаційно-пошукової системи органів внутрішніх справ України [19];

б) Інструкція з організації взаємодії органів досудового розслідування з іншими органами та підрозділами Національної поліції в запобіганні кримінальних правопорушень, їх виявленні та розслідуванні [20];

в) Інструкція з організації розшуку осіб органами внутрішніх справ [21];

г) інші відомчі та міжвідомчі нормативно-правові акти з означених питань.

На орган пробації, як випливає із загальних (Закон України "Про пробацію”) та безпосередніх нормативно-правових джерел (Типове положення про уповноважений орган 3 питань пробації), покладається виконання й інших обов'язків, які варто було зазначити в ч. 1 ст. 31 КВК України у вигляді відповідної ремарки: “виконує інші обов’язки, що визначені в законі”.

Висновок. Отже, для виконання обов'язків уповноваженим органом з питань пробації щодо виконання покарання у вигляді позбавлення права обіймати певні посади або займатися певною діяльністю, зокрема і щодо засуджених у сфері пенсійного та соціального законодавства України, мають бути на нормативно-правовому рівні створені відповідні правові гарантії, а для забезпечення їх якості та ефективності - організаційні, управлінські, матеріально-технічні та інші умови.

\section{СПИСОК ВИКОРИСТАНИХ ДЖЕРЕЛ}

1. Конституція України: чинне законодавство станом на 16 січня 2019 р.: Офіц. текст. Київ: Алерта, 2019. 80 с. 2. Великий тлумачний словник сучасної української мови / укл. О. Єременко. Донецьк: ТОВ “Глорія Трейд”, 2012. 864 с. 3. Теорія держави і права: підручник для студ. юрид. вищ. навч. закл. / О. В. Петришин, С. П. Погребняік, В. С. Смородинський та ін.; за ред. О. В. Петришина. Харків: Право, 2014. 368 с. 4. Булыко А. Н. Большой словарь иностранных слов. 35 тысяч слов. Изд. 3-е, испр., перераб. Москва: Мартин, 2010. 704 с. 5. Кримінально-виконавчий кодекс України: прийнятий 11 липня 2003 року. Відомості Верховної Ради України. 2004. № 3-4. С. 21. 6. Про пробацію: Закон України від 5 лютого 2015 року № 160-VIII. Відомості Верховної Ради України. 2015. № 13. С. 93. 7. Про затвердження Типового положення про уповноважений орган 3 питань пробації та Типового положення про сектор ювенальної пробації: наказ Міністерства юстиції України від 18 серпня 2017 року № 2649/5. Офіиійиний вісник України. 2017. № 72. С. 22-38. 8. Яковець I. С. Теоретичні та практичні засади оптимізації процесу виконання кримінальних покарань: монографія. Харків: Право, 2013. 392 с. 9. Кельман М. С., Котуха О. С., Коваль І. М. Загальна теорія держави і права: підручник / за заг. ред. д.ю.н., проф. М. С. Кельмана. Тернопіль: ТОВ Терно-граф, 2018. 804 с. 10. Науково-практичний коментар Кримінально-виконавчого кодексу України / А. П. Гель, О. Г. Колб, В. О. Корчинський та ін.; за заг. ред. А. Х. Степанюка. Київ: Юрінком Інтер, 2008. 496 с. 11. Кримінальний кодекс України: прийнятий 5 квітня 2001 року. Відомості Верховної Ради України. 2001. № 25-26. Ст. 131. 12. Деякі питання документування управлінської діяльності: Постанова Кабінету Міністрів України від 17 січня 2018 р. № 55. Офіиійний вісник Украӥни. 2018. № 23. Ст. 770. 13. Кримінальний процесуальний кодекс України: прийнятий 13 квітня 2012 року. Відомості Верховної Ради України. 2013. № 9-10; № 11-12; № 13. С. 88. 14. Про оперативно-розшукову діяльність: Закон України від 18.02 .1992 р. Відомості Верховної Ради України. 1992. № 22. Ст. 303. 15. Кримінальний процесуальний кодекс України: 
науково-практичний коментар: у 2 т. Т. 1 / О. М. Бандурка, Є. М. Блажієвський, Є. П. Бурдаль; за заг. ред. Я. Я. Тація. Харків: Право, 2012. 768 с. 16. Цивільний кодекс України. Відомості Верховної Ради України. 2003. № 40. Ст. 356. 17. Про практику призначення судами кримінального покарання: постанова Пленуму Верховного Суду України в кримінальних справах / упоряд. В. В. Рожнова, А. С. Сизоненко, Л. Д. Удалова. Київ: ПАЛИВОДА А.В., 2011. С. 231-245. 18. Про прокуратуру: Закон України від 14 жовт. 2014 р. № 1697-VII. Верховна Рада України. URL: http://zakon3.rada.gov. ua/laws/show/1697-18. 19. Інструкція 3 організації функціонування Інтегрованої інформаційнопошукової системи органів внутрішніх справ України: затв. Наказом МВС України від 10.03.2010 р. № 75. URL: https://www.slideshare.net/krapzen/10032010-75 20. Інструкція з організації взаємодії органів досудового розслідування з іншими органами та підрозділами Національної поліції України в запобіганні кримінальним правопорушенням, їх виявленні та розслідуванні: затв. наказом МВС України від 07.07.2017 р. № 575. Офіиійний вісник України. 2017. № 67. Ст. 2019. 21. Інструкція 3 організації розшуку осіб органами внутрішніх справ: затв. Наказом МВС України від 29.07.2002 р. № 765 ДСК. URL: https://zakon.rada.gov.ua/laws/show/ru/z0676-02.

\section{REFERENCES}

1. Konstytutsiia Ukrainy [Constitution of Ukraine]: chynne zakonodavstvo stanom na 16 sichnia 2019 r.: [Officer. text] Ofits. tekst. Kyiv: Alerta, 2019. 80 p. 2. Velykyi tlumachnyi slovnyk suchasnoi ukrainskoi movy [Great explanatory dictionary of contemporary Ukrainian language] / ukl. O. Yeremenko. Donetsk: TOV "Hloriia Treid", 2012. 864 p. 3. Teoriia derzhavy i prava: pidruch. [The theory of state and law: under the arm] Dlia stud. yuryd. vyshch. navch. zakl. / O. V. Petryshyn, S. P. Pohrebniaik, V. S. Smorodynskyi ta in.; za red. O. V. Petryshyna. Kharkiv: Pravo, 2014. 368 p. 4. Bulko A. N. Bolshoi slovar ynostrannkh slov. 35 tsiach slov [Great Dictionary of Foreign Languages. 35 thousand words]. Yzd. 3-e, yspr., pererab. Moskva: Martyn, 2010. 704 p. 5. Kryminalno-vykonavchyi kodeks Ukrainy: pryiniatyi 11 lypnia 2003 roku [The Criminal-Executive Code of Ukraine]. Vidomosti Verkhovnoi Rady Ukrainy [Information from the Verkhovna Rada of Ukraine], 2004. No. 3-4. P. 21. 6. Pro probatsiiu: Zakon Ukrainy vid 5 liutoho 2015 roku No. 160-VIII. [On probation]. Vidomosti Verkhovnoi Rady Ukrainy [Information from the Verkhovna Rada of Ukraine]. 2015. No. 13. P. 93. 7. Pro zatverdzhennia Typovoho polozhennia pro upovnovazhenyi orhan z pytan probatsii ta Typovoho polozhennia pro sektor yuvenalnoi probatsii: nakaz Ministerstva yustytsii Ukrainy vid 18 serpnia 2017 roku No. 2649/5 [On Approval of the Model Provision on the Authorized Body on Probation and the Model Provision on the Juvenile Probation Sector ]. Ofitsiinyi visnyk Ukrainy. 2017. No. 72. P. 22-38. 8. Yakovets I. S. Teoretychni ta praktychni zasady optymizatsii protsesu vykonannia kryminalnykh pokaran: monohrafiia [Theoretical and practical principles of optimization of the process of execution of criminal punishments: monograph]. Kharkiv: Pravo, 2013. 392 p. 9. Kelman M. S., Kotukha O. S., Koval I. M. Zahalna teoriia derzhavy i prava: pidruchnyk [General theory of state and law: textbook] / za zah. red. d.yu.n., prof. M. S. Kelmana. Ternopil: TOV Ternohraf, 2018. 804 p. 10. Naukovo-praktychnyi komentar Kryminalno-vykonavchoho kodeksu Ukrainy [Scientific and Practical Commentary of the Criminal-Executive Code of Ukraine] / A. P. Hel, O. H. Kolb, V. O. Korchynskyi ta in.; za zah. red. A. Kh. Stepaniuka. Kyiv: Yurinkom Inter, 2008. 496 p. 11. Kryminalnyi kodeks Ukrainy: pryiniatyi 5 kvitnia 2001 roku [The Criminal Code of Ukraine]. Vidomosti Verkhovnoi Rady Ukrainy. 2001. No. 25-26. P. 131. 12. Deiaki pytannia dokumentuvannia upravlinskoi diialnosti: Postanova Kabinetu Ministriv Ukrainy vid 17 sichnia 2018 r. No. 55 [Some issues of documenting management activities]. Ofitsiinyi visnyk Ukrainy. 2018. No. 23. P. 770. 13. Kryminalnyi protsesualnyi kodeks Ukrainy: pryiniatyi 13 kvitnia 2012 roku [The Criminal Procedural Code of Ukraine]. Vidomosti Verkhovnoi Rady Ukrainy. 2013. No. 9-10; No. 11-12; No. 13. P. 88. 14. Pro operatyvno-rozshukovu diialnist: Zakon Ukrainy vid 18.02.1992 $r$. [On Operational and Investigative Activity]. Vidomosti Verkhovnoi Rady Ukrainy. 1992. No. 22. P. 303. 15. Kryminalnyi protsesualnyi kodeks Ukrainy. Naukovo-praktychnyi komentar: u 2 t. T. 1 [The Criminal Procedural Code of Ukraine. Scientific and Practical Comment] / O. M. Bandurka, Ye. M. Blazhiievskyi, Ye. P. Burdal; za zah. red. Ya. Ya. Tatsiia. Kharkiv: Pravo, 2012. 768 p. 16. Tsyvilnyi kodeks Ukrainy. [Civil Code of Ukraine]. Vidomosti Verkhovnoi Rady Ukrainy. 2003. No. 40. P. 356. 17. Pro praktyku pryznachennia sudamy 
kryminalnoho pokarannia: postanova Plenumu Verkhovnoho Sudu Ukrainy v kryminalnykh spravakh [About the practice of appointment of criminal penalties by courts: resolution of the Plenum of the Supreme Court of Ukraine in criminal cases] / uporiad. V. V. Rozhnova, A. S. Syzonenko, L. D. Udalova. Kyiv: PALYVODA A.V., 2011. P. 231-245. 18. Pro prokuraturu: Zakon Ukrainy vid 14 zhovt. 2014 r. No. 1697-VII [About the prosecutor's office]. Verkhovna Rada Ukrainy. URL: http://zakon3.rada.gov.ua/ laws/show/1697-18. 19. Instruktsiia $z$ orhanizatsii funktsionuvannia Intehrovanoi informatsiinoposhukovoi systemy orhaniv vnutrishnikh sprav Ukrainy: zatv. Nakazom MVS Ukrainy vid 10.03.2010 r. No. 75 [ Instruction on the organization of the functioning of the Integrated Information Retrieval System of the Ministry of Internal Affairs of Ukraine]. URL: https://www.slideshare.net/krapzen/10032010-75. 20. Instruktsiia $z$ orhanizatsii vzaiemodii orhaniv dosudovoho rozsliduvannia $z$ inshymy orhanamy ta pidrozdilamy Natsionalnoi politsii Ukrainy $v$ zapobihanni kryminalnym pravoporushenniam, yikh vyiavlenni ta rozsliduvanni: zatv. nakazom MVS Ukrainy vid 07.07.2017 r. No. 575. [Instruction on organization of interaction of pre-trial investigation bodies with other bodies and units of the National Police of Ukraine in the prevention of criminal offenses, their detection and investigation]. Ofitsiinyi visnyk Ukrainy. 2017. No. 67. P. 2019. 21. Instruktsiia z orhanizatsii rozshuku osib orhanamy vnutrishnikh sprav: zatv. Nakazom MVS Ukrainy vid 29.07.2002 r. No. 765 DSK. [Instruction on organization of search for persons by internal affairs bodies]. URL: https://zakon.rada.gov.ua/laws/show/ru/z0676-02.

Дата надходження: 06.08.2019 p. 